\title{
Reducing torque pulsations in PMa-SynRM: a way for improving motor performance
}

\author{
Percy R. Viego ${ }^{1}$, Julio R. Gómez 2 , Vladimir Sousa ${ }^{3}$, José P. Monteagudo Yanes ${ }^{4}$, Enrique C. Quispe ${ }^{5}$ \\ ${ }^{1,2,4}$ Center of Energy and Environmental Studie, Universidad de Cienfuegos, Cuba \\ ${ }^{3}$ Energy Department, Universidad de la Costa, Barranquilla, Colombia \\ ${ }^{5}$ Energy and Mechanical Department, Universidad Autónoma de Occidente, Cali, Colombia
}

\begin{tabular}{l} 
Article Info \\
\hline Article history: \\
Received Aug 31, 2020 \\
Revised Jan 19, 2021 \\
Accepted Jan 29, 2021 \\
\hline Keywords: \\
Cogging torque \\
Economic analysis \\
Permanent magnet motor drives \\
Synchronous reluctance motor \\
drives \\
Torque ripple
\end{tabular}

Article Info

Article history:

Received Aug 31, 2020

Revised Jan 19, 2021

Keywords:

Cogging torque

Economic analysi

\begin{abstract}
This paper aims to evaluate the performance of synchronous reluctance motors assisted by a permanent magnet (PMa-SynRM) focused on efficiency and torque pulsations. PMa-SynRM shows high efficiency and power factor, compared to induction motors (IM), although they have a greater cost. These machines develop relatively high torque ripple, cogging torque, and torque imbalances. Consequently, the electromagnetic torque is reduced, the motor temperature is increased, and mechanical vibrations are induced. The optimal design of the machine structures such as flow barriers, permanent magnets, and stator slots, among others, allow reducing torque pulsations. A comparison is made between different designs of the PMa-SynRM reported in the scientific literature, and the effects on efficiency, torque pulsation, and operating costs are evaluated. A case study on the motor driving the air conditioner blower in a hotel room was made, to determine the best economic variant between IM or PMa-SynRM. A sensitive analysis was made to evaluate several uncertainties. The advantages of using one of the PMa-SynRM analyzed were demonstrated. Also, it was proved that the investment is feasible economically, although NPV and payback are not the best, due to low load factor in inverter-controlled motors in air conditioners.
\end{abstract}

This is an open access article under the CC BY-SA license.

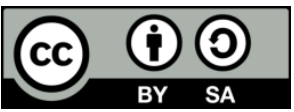

Corresponding Author:

Vladimir Sousa Santos

Energy Department

Universidad de la Costa

Calle 58 No.55-66, Barranquilla, Colombia

Email: vsousa1@cuc.edu.co

\section{INTRODUCTION}

Electric motors are among the main consumers of electrical energy, representing around $50 \%$ of world consumption and around $67 \%$ of electricity consumption in the industrial sector [1], [2]. Due to this, technologies such as solid-state adjustable voltage-frequency controllers [3], [4] and regulatory mechanisms such as minimum energy-efficiency performance standards (MEPS) have been implemented [5] to reduce the consumption of electrical energy in the motors. MEPS aims the gradually commercialize and use motors with high levels of efficiency such as IE4 (super-premium) and IE5 (ultra-premium) [5], [6].

The high demand to achieve these levels of efficiency has driven the development and design of new technologies in electric motors. Emerging technologies include permanent magnet synchronous motors, synchronous reluctance motors, and a combination of these technologies such as synchronous reluctance motors assisted by a permanent magnet (PMa-SynRM) [6]-[8].

PMa-SynRM shows high efficiency and power factor compared to induction motors (IM), although they have a greater cost. Both their design and their manufacture are complex [9]. Furthermore, these 
machines develop relatively high torque pulsations [10]-[12]. The high torque pulsations are due to the complex structure of the PMa-SynRM. Figure 1 (a) shows the structure of a PMa-SynRM without the permanent magnets (PM) in place. In Figure 1 (b), the details of the structure of a rotor lamination with the $\mathrm{PM}$ inserted are given [13].

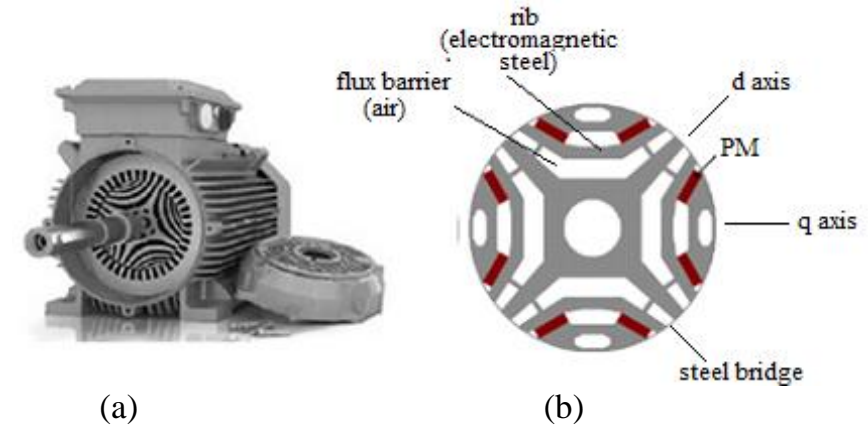

Figure 1. Structural details of a PMa-SynRM, a) PMa-SynRM without the PM in place, b) Rotor lamination arrangement with de PM in place [13]

The torque pulsations have two main components: torque ripple and cogging torque. Besides, this machine presents important mechanical and magnetic imbalances. As a result, the average electromagnetic torque is reduced [14], the motor temperature is increased, and unwanted mechanical vibrations are induced, causing noise and premature bearing aging and the reduction of the life span [15]-[19]. Additionally, they can affect the stability of motor control, especially at high speeds.

Torque ripple results from the interaction between the spatial harmonics of the stator magnetomotive force and the air gap permeance. They are high, due to the toothed structure and the presence of PM in the PMa-SynRM. So, in this type of motor, reducing torque pulsation is one of the highest priorities in its development. The percent of (\% Tripple) is the relationship between the variations of the peak-to-peak torque $(\Delta \mathrm{Tpp})$ to the average torque (Tave) in an electric cycle. It is given by (1).

$$
\% T_{\text {ripple }}=\frac{\Delta T_{p p}}{T_{\text {ave }}} 100
$$

In Figure 2 a torque wave is given, where: average torque is 5.1; peak-to-peak torque is $0.867 \mathrm{Nm}$, and the percentage of torque ripple is $17 \%$ [9].

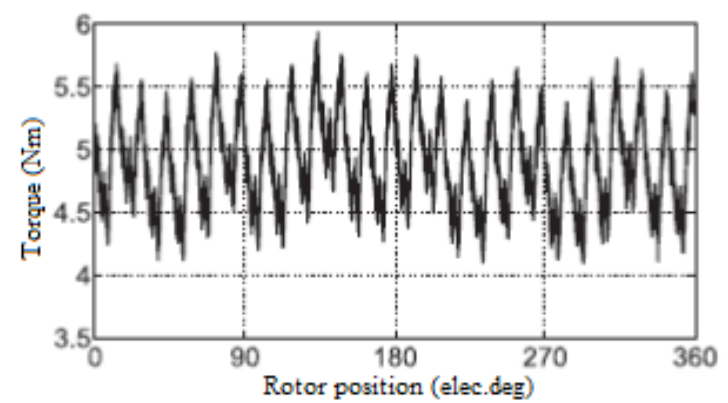

Figure 2. Torque wave [9]

Cogging torque occurs primarily when the sides of the stator teeth match the sides of the rotor teeth and a torque component is required to break the attraction that occurs. Another common cause of cogging torque is due to slight asymmetries in the magnetic field generated by the windings, which cause variations in reluctance, depending on the rotor position [20]. The contribution of this paper is the evaluation of the performance of the operation of PMa-SynRM focused on efficiency and torque pulsations, specifically the 
problems of torque ripple and cogging torque are assesed. In several works the operation of PMa-SynRM has been analyzed [15]-[19], however, none of them is an analysis with the approach proposed in this study.

Firstly, an analysis of optimized PMa-SynRM design dimensions to reduce torque pulsations is carried out. A comparison between different variants of this motor is made to evaluate the effects on operational characteristics and advantages and disadvantages in other factors, including costs. A case study on the motor that drives the air conditioner blower in a hotel room was made, to determine the best variant: employing an IM or one of three PMa-SynRM types obtained. The advantages of using one of the PMaSynRM was demonstrated.

\section{RESEARCH METHOD}

\subsection{Effects of rotor design parameters on torque pulsations}

The most important difficulty encountered in the design and operation of the PMa-SynRM is torque ripple. When studying the bibliography related to the reduction of this phenomenon, it is evident that among the design parameters that more affect torque ripple is: the number of rotor flux barriers, stator slots/rotor flux barriers, quantity position of PM and insulation ratios ( $\mathrm{kq}$ and $\mathrm{kd})$. In [21] a design procedure is developed for a PMa-SynRM of a washing machine, based on a finite element software. The objective is to achieve the best design that gives the rated average torque induced, with minimal torque ripple. The rated motor values are $1.1 \mathrm{Nm}, 563 \mathrm{rpm}$, and $1.62 \mathrm{~A}$ for the washing mode and $0.2 \mathrm{Nm}, 13200 \mathrm{rpm}$, and $3.2 \mathrm{~A}$ for the spin mode.

The designed stator has 36 slots, with a distributed three-phase, 4-pole winding, integral slots per pole. The conductor current density selected was $4.7 \mathrm{~A} / \mathrm{mm} 2$ for the washing mode (which demands low power), and $7.4 \mathrm{~A} / \mathrm{mm} 2$ for the spinning mode (which demands high power). In Figure 3, the diagrams to determine the best variant in terms of the number of flux barriers are shown; and in Table 1, the effect that the number of flux barriers causes on average torque and torque ripple for the washing mode case can be observed. Initially, the selected values for $\mathrm{kq}$ and $\mathrm{kd}$ are those given in [22] as optimal $(\mathrm{kq}=0,6$ and $\mathrm{kd}=1)$, which remain constant during the analysis.

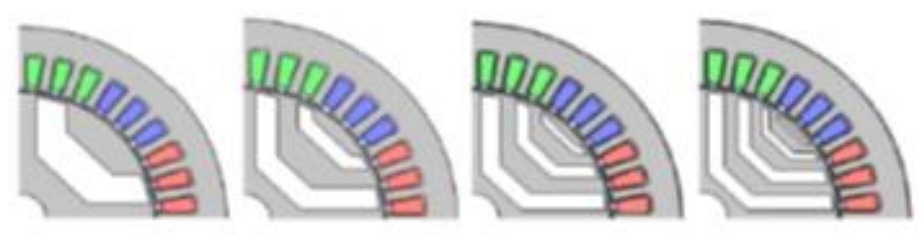

Figure 3. Scheme of the variants with different numbers of flux barriers [22]

Table 1. Effect of the number of barriers on the average torque and torque ripple [22]

\begin{tabular}{lcccc}
\hline \multicolumn{5}{c}{36 slot stator $\left(k_{q}=0.6, k_{d}=1\right)$} \\
\hline & 1 barrier & 2 barriers & 3 barriers & 4 barriers \\
Ave. torque $(\mathrm{Nm})$ & 0.763 & 0.795 & 0.805 & 0.821 \\
Torque ripple $(\%)$ & 15.07 & 13.38 & 10.90 & 9.90 \\
\hline
\end{tabular}

According to Table 1, the best variant is that of 4 barriers. However, considering the dimensions of the motor (with a lamination package of $32 \mathrm{~mm}$ long and $117 \mathrm{~mm}$ of external diameter), it is necessary to select only 3 barriers, to guarantee adequate rigidity and mechanical resistance.

In the next step, the best isolation ratios are determined. It is obtained: $\mathrm{kq}=0.9$ and $\mathrm{kd}=1$, which differ from those obtained in [22]. As for the PM to be inserted in the flux barriers, the best variant is obtained with the following parameters: PM type: ferrite; number of PM and position per pole as depicted in Figure 4 [21]; PM volume: $19.12 \mathrm{~cm} 3$. The data with these model values are given in Table 2. With these results, a prototype was built. The experimental results were satisfactory. 


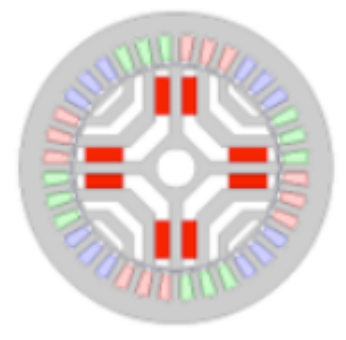

Figure 4. Best variant arrangement [21]

Table 2. Selected model parameters

\begin{tabular}{ccccc}
\hline $\begin{array}{c}\text { Ave. torque } \\
(\mathrm{Nm})\end{array}$ & $\begin{array}{c}\text { Torque ripple } \\
(\%)\end{array}$ & $\begin{array}{c}\text { Current } \\
(\mathrm{A})\end{array}$ & $\begin{array}{c}\text { Efficiency } \\
(\%)\end{array}$ & $\begin{array}{c}\text { Power factor } \\
(\text { p.u. })\end{array}$ \\
\hline 1.345 & 6.7 & 1.6 & 69 & 0.77 \\
\hline
\end{tabular}

One way to reduce cogging torque is by properly arranging the PM in the flux barriers. In Figure 5, PM arrangement for 4 models of a $1.8 \mathrm{~kW}, 4$ poles, 36 slots PMa-SynRM is shown [23]. Table 3 shows the results of torque values. The optimum PMa-SynRM geometry without the PMs is shown in Figure 6 [24].

Table 3. Torque results for the four models [23]

\begin{tabular}{ccccc}
\hline Items & Basic Model & Model 1 & Model 2 & Model 3 \\
\hline Ave. torque $(\mathrm{Nm})$ & 11.77 & 11.35 & 11.73 & 11.83 \\
Cogging torque $(\mathrm{Nm})$ & 0.098 & 0.065 & 0.175 & 0.154 \\
Torque ripple $(\%)$ & 21.8 & 30.8 & 19.3 & 17.6 \\
\hline
\end{tabular}
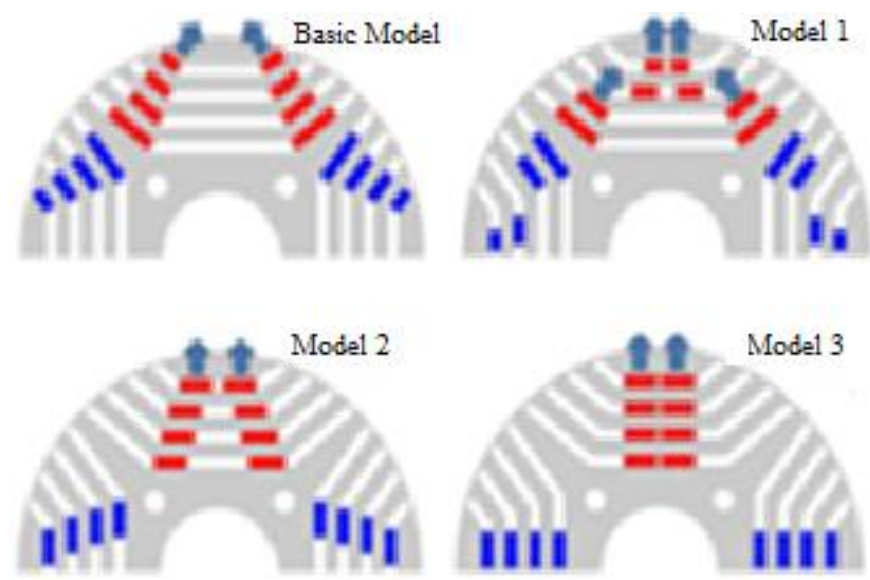

Figure 5. PM arrangement for the 4 models [23]

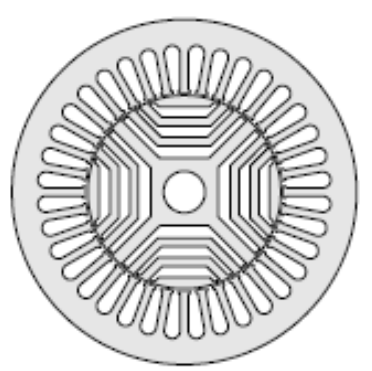

Figure 6. Optimum PMa-SynRM geometry without the PM [24] 
As can be observed in the table, for reducing cogging torque, Model 1 is the best solution but is worth for decreasing torque ripple. On the contrary, the best solution related to torque ripple is using Model 3 [23]. Thereby, the designer must analyze the specific situation for deciding what to do. As in the case analyzed before in [21], the rotor best variant related to flux barrier number is four; but due to the manufacturing difficulties and the mechanical strength, in this study three-layer of flux barriers are selected. When the optimal flux barrier geometry without PM had been achieved, three different cases are studied depending on the inserted PM. In Figure 7, the selected geometry for Case 1 can be observed, where PM is introduced in both base and side sectors, and only in the innermost flux barrier layer. There are three different cases for the comparison:

$>$ Case 1 (C1): Three PM inserted in the innermost flux barrier layer.

$>$ Case 2 (C2): Three PM inserted in the first two innermost flux barrier layers.

$>$ Case 3 (C3): Three PM inserted in all the three flux barrier layers.

In Table 4, some parameters of the three variants $(\mathrm{C} 1, \mathrm{C} 2$, and $\mathrm{C} 3)$ are specified.

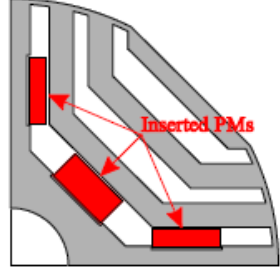

Figure 7. Selected rotor geometry for Case 1 [24]
Table 4. Some specifications of the three motors for air conditioner blowers [24]

\begin{tabular}{lccc}
\hline \multicolumn{1}{c}{ Parameters } & \multicolumn{3}{c}{ PMa-SynRM } \\
& $\mathrm{C} 1$ & $\mathrm{C} 2$ & $\mathrm{C} 3$ \\
\hline Output power (kW) & 0.9 & 0.9 & 0.9 \\
Average torque (Nm) & 6.38 & 6.38 & 6.38 \\
Efficiency (\%) & 91.81 & 93.17 & 93.46 \\
Rated speed (rpm) & 1350 & 1350 & 1350 \\
Operational speed range & $500-$ & $500-$ & $500-$ \\
(rpm) & 1750 & 1750 & 1750 \\
Cost of motors (USD) & 604 & 639 & 686 \\
\hline
\end{tabular}

Case C1 presents the lowest investment (only one layer with PM inserted) but has the worst efficiency; while C3 shows the highest efficiency but has the highest cost (the three layers with PM inserted). $\mathrm{C} 2$ is an intermediate case. So, the variant to be selected will depend on a detailed analysis.

\subsection{Effects of stator design parameters on torque ripple}

Although the rotor design parameters discussed to determine the greatest reduction in torque ripple in PMa-SynRM, the stator design is also important. In [25], a design is developed using a FEM software to obtain the best stator parameters, from a test motor of $1.62 \mathrm{~A}, 563 \mathrm{rpm}, 1.2 \mathrm{Nm}, 4$ poles, 24 slots, 3 flux barriers per pole, and values of $\mathrm{kq}=0.9$ and $\mathrm{kd}=1.0$. The rotor structure remains constant. The stator is identical to that used in a conventional IM. The test machine structure is shown in Figure 8 [22].

Table 5 gives the average of developed torque and torque ripple values for 12, 24, and 36 slots. As is evident, the variant with 36 slots is better.

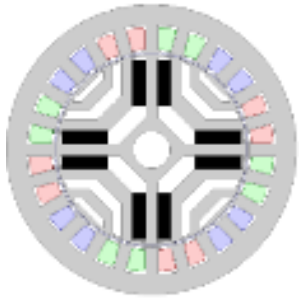

Figure 8. Test motor structure [22]
Table 5. Comparison of the different number of slots in a three-phase distributed winding [22]

\begin{tabular}{ccc}
\hline $\begin{array}{c}\text { Slot } \\
\text { number }\end{array}$ & $\begin{array}{c}\text { Torque } \\
(\mathrm{Nm})\end{array}$ & $\begin{array}{c}\text { Torque ripple } \\
(\%)\end{array}$ \\
\hline 12 & 1.6 & 29.38 \\
24 & 1.52 & 32.89 \\
36 & 1.54 & 7.12 \\
\hline
\end{tabular}

\subsubsection{Stator windings}

The most frequent stator winding configurations in these motors are the distributed integral slots windings and the concentrated fractional slots one [19], [26]. The advantages of concentrated windings over the distributed ones are the significant reduction in copper volume and copper losses possibility of a reduction in the motor total length [27]; a decrease in manufacturing cost; higher slot fills factor. However, 
regarding torque ripples, the use of the concentrated windings seems to have mixed results [28]. So, generally, stator distributed windings, having integral or fractional slots are preferred [29].

In [25] the use of 6 slots/4 poles and 12 slots/4 poles with concentrated windings, was evaluated. It was obtained that, for 6 slots, the average torque was $1.8 \mathrm{Nm}$ and torque ripple $44 \%$, while, for 12 slots, the values were $0.578 \mathrm{Nm}$ and $43.25 \%$, respectively. These high values cause that, in the literature consulted, it is suggested not to use these slots/pole combinations for concentrated or distributed windings. So, it is proposed for a better solution, to use a stator of 36 slots. Also, two variants are compared: single and double layer focused to reduce harmonics. The second layer of the last winding has a fractional coil pitch. The average torque, the torque ripple, and its percentage for each winding are given in Table 6 [25].

Table 6. Comparison between a single- and double-layer distributed windings for 36 slots [25]

\begin{tabular}{cccc}
\hline Layers & $\begin{array}{c}\text { Ave. torque } \\
(\mathrm{Nm})\end{array}$ & $\begin{array}{c}\text { Torque ripple } \\
(\mathrm{Nm})\end{array}$ & $\begin{array}{c}\text { Ripple } \\
(\%)\end{array}$ \\
\hline Single & 1.54 & 0.109 & 7.12 \\
Double & 1.5 & 0.08 & 5.33 \\
\hline
\end{tabular}

The double-layer suppresses the odd 5th, 7th, 11th, 13th harmonics. However, the single-layer has a fundamental component of higher torque than in the double layer. All this analysis serves as an example to show that the type of winding has to be carefully selected and that it must be evaluated for each specific case of application of the PMa-SynRM.

\subsubsection{Slot geometric optimization}

In [25], the slot's geometric optimization is performed. The slot shape, the height of its opening, the tooth bottom rounding, and the wedge height, practically do not at all affect the results, while the slot opening width and the tooth width affect them significantly. The optimization method used in this study can be seen in [25]. The most relevant results on the slot opening and tooth width are described below.

Slot opening, the slot opening causes average torque and torque ripple to change substantially. In Figure 9 a) the slot opening is shown. Table 7 [25] shows that the smaller the opening, the better the results, although it is necessary to analyze if the opening allows or not the use of automatic winding machines, which produce an additional saving in motor cost.

Tooth width, in [17] an experiment with a 36-slots machine is carried out, showing that with closed slots a torque ripple of $13.7 \%$ is produced, while for semi-closed slots it is $18 \%$ and for open slots $22.4 \%$. A cross-section of a motor with closed slots is shown in Figure 9 (b) [18].

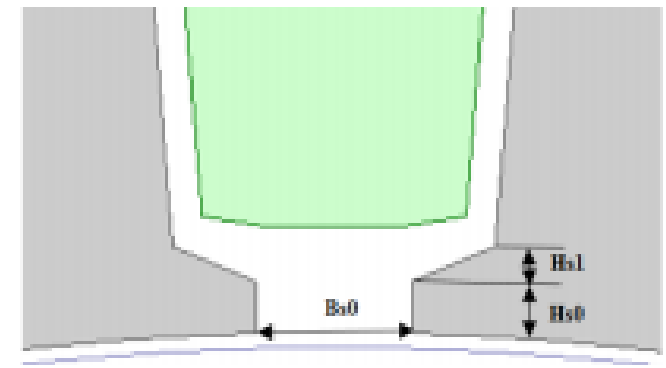

(a)

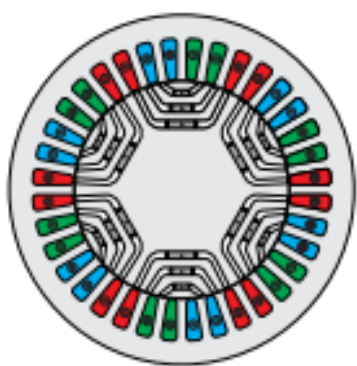

(b)

Figure 9. Stator slots structure of PMa-SynRM, (a) Stator slot opening parameters, (b) Cross-section of a motor with closed slots [17], [18]

Table 7. Average and torque ripple depending on the slot opening [18]

\begin{tabular}{ccc}
\hline $\begin{array}{c}\text { Slot opening } \\
(\mathrm{mm})\end{array}$ & $\begin{array}{c}\text { Ave. Torque } \\
(\mathrm{Nm})\end{array}$ & $\begin{array}{c}\text { Torque ripple } \\
(\%)\end{array}$ \\
\hline 4 & 1.313 & 9.52 \\
3 & 1.426 & 8.63 \\
2 & 1.530 & 7.12 \\
1 & 1.605 & 5.79 \\
\hline
\end{tabular}


Although the average torque decreases somewhat with closed slots, the speed also increases slightly, so the power output is rarely affected. The same author reports that there are some techniques to close the stator slots after the winding process using ferromagnetic wedges, which reduces the economic impact. The effects of varying the tooth width are evaluated by keeping the total slot area constant while keeping equal the diameter of the stator. Table 8 shows the variation of average torque and torque ripple with the tooth width.

\begin{tabular}{cccc} 
Table 8. Torque and torque ripple variation with tooth width [18] \\
$\begin{array}{c}\text { Tooth width } \\
(\mathrm{mm})\end{array}$ & $\begin{array}{c}\text { Ave. torque } \\
(\mathrm{Nm})\end{array}$ & $\begin{array}{c}\text { Torque ripple } \\
(\mathrm{Nm})\end{array}$ & $\begin{array}{c}\text { Torque ripple } \\
(\%)\end{array}$ \\
\hline 4.540 & 1.558 & 0.085 & 5.460 \\
4.090 & 1.600 & 0.090 & 5.630 \\
3.638 & 1.610 & 0.095 & 5.900 \\
3.185 & 1.613 & 0.096 & 5.950 \\
\hline
\end{tabular}

\subsection{Other measures for reducing torque pulsations}

\subsubsection{Skewing}

For avoiding the cogging torque that appears when the stator and rotor tooth sides are in alignment, the slots skew may be applied. The skew can be carried out on the stator or the rotor, so that the intersection occurs not in a straight line, but in an inclined way, making the corresponding effect more gradual. Skewing in the stator is the most conventional and effective method of reducing cogging torque. Besides, skew diminish torque ripple. However, it must also be considered that this measure makes the winding slightly longer, its resistance increases in proportion, and the efficiency decrease lightly [30] Another difficulty is that skewing does not propitiate automatic winding which adds cost in motor manufacture. However, manufacturers can stack the laminations, insert slot liners, place the coils and after that, the stack of laminations is skewed. Afterward, the stack is welded to hold it in place. This process is essentially identical to conventional manufacturing, except that welding is done after the coils are inserted, rather than before.

\subsubsection{Skew-notching}

In [30] another method is proposed to reduce the cogging torque and practically eliminate the torque ripple, using skewing and notches in the stator slots. In Figure 10, the scheme of a PMa-SynRM with these characteristics can be seen [30].

Figure 11 shows how cogging torque varies with different rotor positions in a PMA-SynRM. The peak values of that torque, with teeth without notches and with skewing and notching are $1.26 \mathrm{~N}-\mathrm{m}$ and 0.49 $\mathrm{N}-\mathrm{m}$, respectively. This demonstrates that cogging torque is greatly reduced [30].

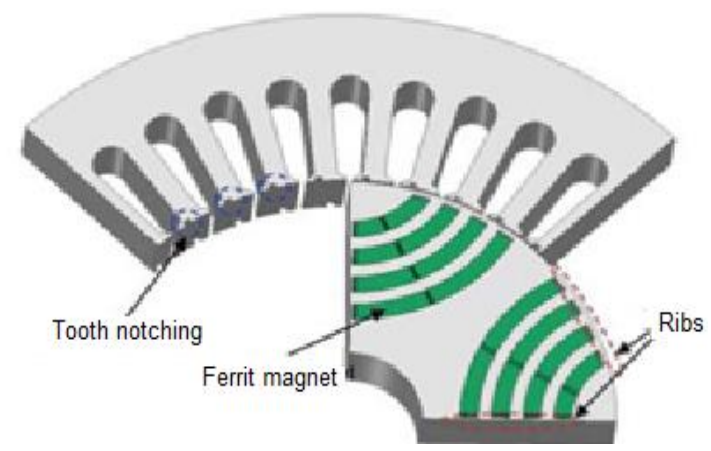

Figure 10. Scheme of a PMA-SynRM with skewnotching in the stator slots [30]

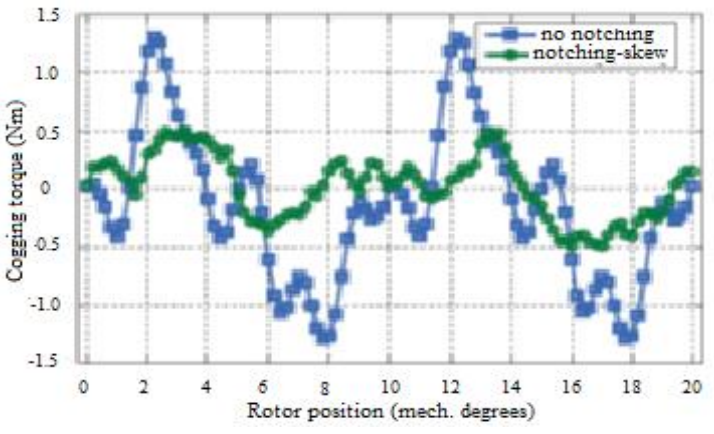

Figure 11. Cogging torque variation with rotor position [30]

\section{RESULTS AND DISCUSSIONS}

\subsection{Economic analysis: a case study}

To achieve the best solution for obtaining savings in the air conditioner motor driving blowers in a Cuban beach hotel having 222 rooms, a case study was implemented. A comparison was studied to know the best variant: employing an IM or one of the three PMa-SynRM types analyzed above $(\mathrm{C} 1, \mathrm{C} 2$, or C3). Data of the last three motors are given in Table 4. All the motors are of $900 \mathrm{~W}, 1350 \mathrm{rpm}$, efficiency class IE4. 
The analysis was accomplished employing the differential net present value (NPV) discount method, which allows eliminating equal (or quasi equal) costs, for example, installation and maintenance costs. NPV is calculated as (2) [31]:

$$
N P V=-k_{0}+\sum_{i=1}^{n} \frac{C_{f_{i}}}{(1+D)^{i}}
$$

Where: $\mathrm{k} 0$ is the investment cost, $\mathrm{D}$ is the tax rate, $\mathrm{n}$ is the life span of the investment, $\mathrm{i}$ is the year of evaluation and $\mathrm{Cf}$ is the cash flow calculated as (3):

$$
C_{f_{i}}=\left(I_{i}-G_{i}-D e p\right) \cdot\left(1-\frac{t}{100}\right)+D e p
$$

Where: $I$ is the income, $G$ the outcome, the interest rate, and Dep the depreciation of the technology calculated as (4) [32]:

$$
\text { Dep }=\frac{k_{0}}{n}
$$

Differential NPV is the difference between the NPV obtained for each substitution option analyzed (i.e. PMa-SynRM (C1), (C2), and (C3)) concerning the NPV of the IM. The investment payback period is the year (i) for which NPV $=0$. The main parameters, for a base economic analysis, are shown in Table 9 [24], [33]-[37]. $\mathrm{K}$ factor is a coefficient applied to the energy cost for considering the variation of fuel costs during the life span, it has a nonlinear behavior [34], [35]. The investment cost is the cost of the motors, the economic income is the energy savings calculated as the difference between the energy consumption of the PMa-SynRM (C1), (C2), and (C3) about IM, and considering the price of electricity according to the M1A tariff and the k factor [34], [35]. The outcomes are the maintenance and installation costs that are eliminated in the calculation of the differential NPV.

Table 9. Main parameters for the study

\begin{tabular}{lcccc}
\hline \multicolumn{1}{c}{ Parameters } & IM & PMa-SynRM (C1) & PMa-SynRM (C2) & PMa-SynRM (C3) \\
\hline Rated output power (kW) & 0.9 & 0.9 & 0.9 & 0.9 \\
Efficiency class & IE4 & IE4 & IE4 & IE4 \\
Efficiency (\%) & 86,5 & 91.81 & 93.17 & 93.46 \\
Rated speed (rpm) & 1350 & 1350 & 1350 & 1350 \\
Operational speed range (rpm) & $500-1750$ & $500-1750$ & $500-1750$ & $500-1750$ \\
Load factor weighted average & 0.45 & 0.45 & 0.45 & 0.45 \\
Operational hours per year & 5000 & 5000 & 5000 & 5000 \\
Investment cost (USD) & 555 & 604 & 639 & 686 \\
Motor live span (years) & 10 & 10 & 10 & 10 \\
Electric tariff & M1 A & M1 A & 3.9 & M1 A \\
Initial $K$ factor & 3.9 & 3.9 & 35 & 3.9 \\
Tax rate $(\%)$ & 35 & 35 & 15 & 35 \\
Interest rate $(\%)$ & 15 & 15 & & 15 \\
\hline
\end{tabular}

The load factor weighted average is calculated applying (5) for the typical case of HVAC uses, taking the values shown in Table 10 [38].

$$
L F W A=\frac{\sum P R F R \cdot P T S}{\sum P T S}
$$

Where LFWA is the load factor weighted average, PRFR is the percent of rated flow rate, and PTS the percent timeshare.

Table 10. Load profile for typical HVAC uses

\begin{tabular}{cc}
\hline Percent of rated flow rate (\%) & Percent time share (\%) \\
\hline 25 & 45 \\
50 & 35 \\
75 & 15 \\
100 & 5 \\
\hline
\end{tabular}


With the load factor weighted average and the efficiency of Table 6 , the electrical power and energy consumption are calculated for each case with (6)(7)(8) [5]:

$$
\begin{aligned}
& P_{\text {out }}=P R F R \cdot P_{r} \\
& P_{\text {in }}=\frac{P_{\text {out }}}{\eta} \\
& E=P_{\text {in }} \cdot t
\end{aligned}
$$

Where Pout is the operational mechanical power, Pr is the rated output power, Pin is the electrical power, $\mathrm{E}$ is the energy consumption and $\mathrm{t}$ is the operational hours per year. The results obtained from the economic analysis can be seen in Table 11.

Table 11. Main economic results

\begin{tabular}{cccc}
\hline Motor variants & $\begin{array}{c}\text { Differential investment } \\
\text { (USD) }\end{array}$ & $\begin{array}{c}\text { Differential NPV } \\
\text { (USD) }\end{array}$ & $\begin{array}{c}\text { Payback } \\
\text { (years) }\end{array}$ \\
\hline PMa-SynRM (C1) - IM & 49 & 55.2 & 4 \\
PMa-SynRM (C2) - IM & 84 & 49,3 & 6 \\
PMa-SynRM (C3) - IM & 131 & 2.02 & 10 \\
\hline
\end{tabular}

Where the investment differential is the difference in the cost of (PMa-SynRM (C1), (C2), (C3)) about the IM. The best results were achieved with the variant PMa-SynRM (C1) since it has the highest NPV and a payback of four years. This is a good solution, considering the case of a motor for an air conditioner blower driven by an inverter control, which implies an unavoidable low load factor. According to [37], based on the generality of cases of the HVAC field, when the efficiency gain moving from one equipment to another more efficient, may not be enough to justify the additional initial investment. That is the case shown in Table 11. Since it is necessary to evaluate the effect of some technical and economic uncertainties, a multifactorial sensitivity analysis was done, as it is shown below.

\subsection{Sensitivity analysis}

Uncertainty in the economic analysis due to variations in economic indicators and other factors has a marked influence on the results of a proposed feasibility study. For this reason, a sensitivity analysis is performed to validate the proposal in the face of possible variations in the most influential factors. The study analyzed how the NPV and the payback behave with variations in operating economic factors. The base case is the PMa-SynRM (C1) with the data from tables 9 and 10. For this study, the differential investment cost, the annual operational time, and the growth rate of the fuel factor (factor K) were varied in equations (2), (3), and (4), keeping the load factor constant. The growth rate of the fuel factor is indicative of variations in the energy price. The initial $\mathrm{K}$ factor considered in the base case is 3.9 ; it varies annually by $8 \%$ according to (9):

$$
K=3.9 \cdot(1+k)^{n}
$$

Where: $\mathrm{k}$ is the annual growth rate of the fuel factor and $\mathrm{n}$ is the year analyzed. The results of the analysis are shown in Figures 12 to 14 obtained in Excel.

Figures 12 (a) and 12 (b) show the variation of the NPV and the payback on investment, respectively, to the variations in the differential cost of investment for a growth rate of the $\mathrm{K}$ factor equal to $8 \%$ and 5000 hours of operation. As can be seen in Figure 12, the NPV decreases with increases in the differential cost, making the investment less attractive. For differential costs above 55 USD, the NPV becomes even less than the incremental investment and the payback period is greater than 4 years.

Figure 13 (a) and (b) present the variation of NPV and payback, respectively, before variations in the $\mathrm{K}$ factor growth rate of $8 \%$ for a differential cost of 49 USD and 5,000 hours of operation. Figure 13 (a) shows that increases in energy prices (through increases in K) lead to increases in NPV. However, it has little influence on the payback (as shown in Figure 13 (b).

In Figure 14 (a) and (b) can be seen variations of NPV and payback, respectively, related to annual operational time for variations in the $\mathrm{K}$ factor growth rate of $8 \%$ and a differential cost of 49 USD. The operational time has the same effect on NPV as the variation in the price of energy depicted in Figure 14 (a). For operational times of less than $5000 \mathrm{~h}$ /year, the payback reaches unattractive economic values as shown in Figure 14 (b). This sensitivity analysis demonstrated that in the case of air conditioners, the study must be handled carefully. 


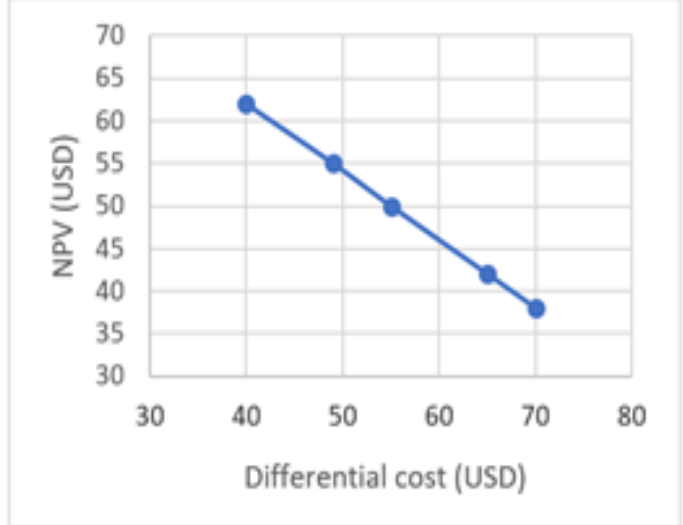

(a)

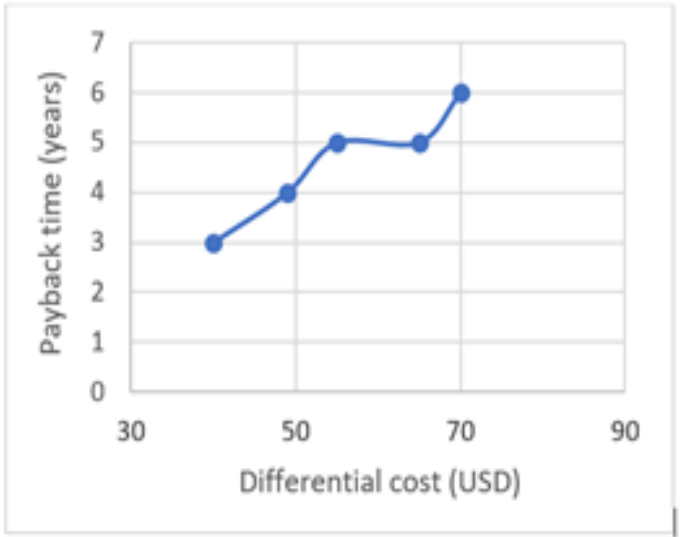

(b)

Figure 12. Variation of NPV and payback vs. differential cost, (a) NPV, (b) payback

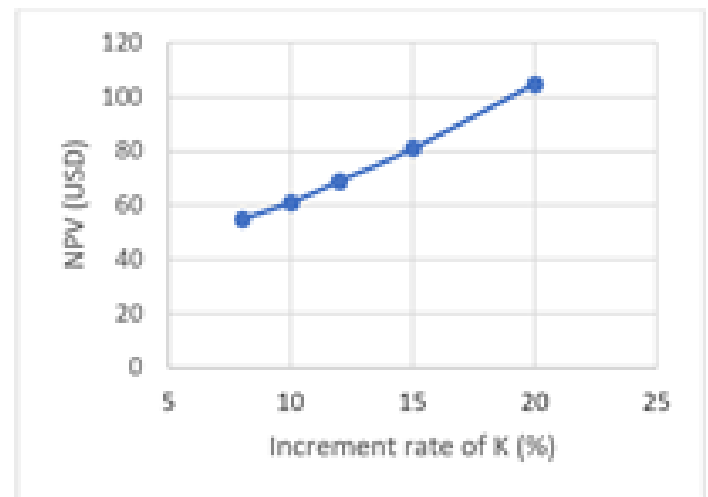

(a)

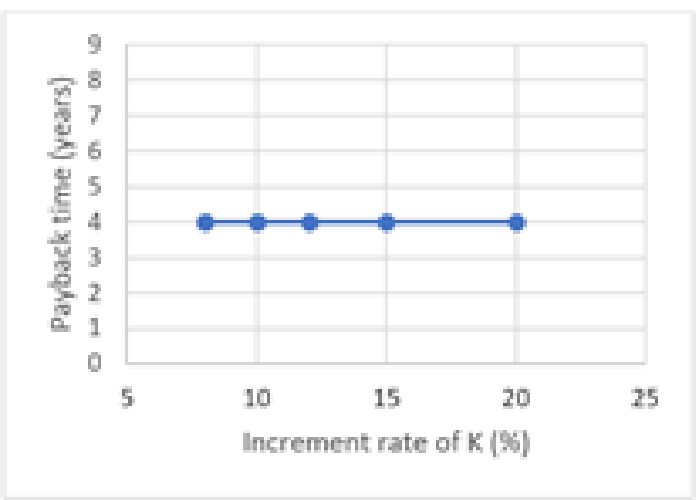

(b)

Figure 13. Variation of NPV and payback vs. $K$ factor increase rate, (a) NPV, (b) payback

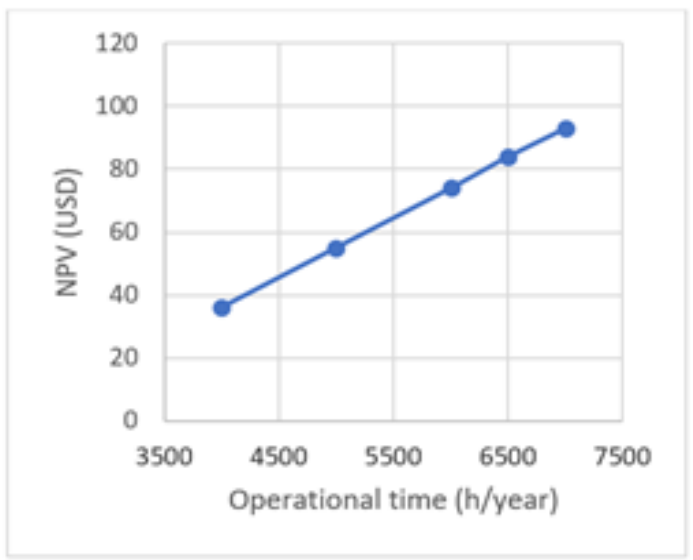

(a)

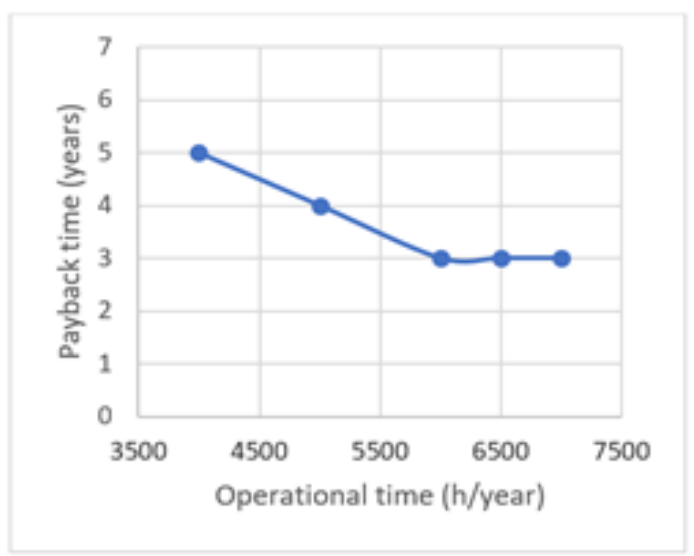

(b)

Figure 14. Variation of NPV and payback vs. operational time (a) NPV, (b) payback

\section{CONCLUSION}

Analysis of different design elements and structural optimization of PMa-SynRM allowed demonstrating that the reduction of torque pulsations can be achieved by adjusting the number, shape, 
position, and volume of permanent magnets, the number of stator slots, and other structural parameters. A comparison between different variants of this type of motor was made, for evaluating the effects on operational characteristics and in other factors as costs. A case study on the motor driving the air conditioners of a hotel room was developed, for determining the best variant: employing an IM or one of three PMaSynRM types.

The economic analysis was accomplished employing the differential net present value discount method. The better solution was a PMa-SynRM with a differential investment of 49 USD, a differential NPV of 55.2 USD, and a payback of 4 years. Although NPV and payback are not the best, due to unavoidable low load factors in the inverter-controlled motor in air conditioners, it was proved that the investment was feasible economically. The uncertainties of three variables were evaluated through a sensitivity analysis. This analysis demonstrated that in the case of air conditioners, the study should be treated with care.

\section{REFERENCES}

[1] L. Collazo, et al., "A new exact equivalent circuit of the medium voltage three-phase induction motor," International Journal of Electrical and Computer Engineering (IJECE). vol. 10, no. 6, pp. 6164-6171, 2020.

[2] V. Sousa, et al, "Estimating induction motor efficiency under no-controlled conditions in the presences of unbalanced and harmonics voltages," in 2015 CHILEAN Conference on electrical, electronics engineering, information and communication technologies (CHILECON), pp. 567-572, 2015.

[3] V. Sousa, et al., "Harmonic distortion evaluation generated by PMW motor drives in electrical industrial systems," International Journal of Electrical and Computer Engineering (IJECE), vol. 7, no. 6, pp. 3207-3216, 2017.

[4] D. R. Quintero, et al., "Methodology to measure electric discharge machining (EDM) bearing currents in induction motors with supply from a variable speed drive (VSD)," INGE CUC, vol. 9, no. 2, pp. 83-93, 2013.

[5] V. Sousa, et al., "Assessment of the energy efficiency estimation methods on induction motors considering realtime monitoring," Measurement, vol. 136, pp. 237-247, 2019.

[6] A. T. de Almeida, et al., "Beyond induction motors - technology trends to move up efficiency," IEEE Transactions on Industry Applications, vol. 50, no. 3, pp. 2103-2114, 2014.

[7] E. I. Mbadiwe, et al., "Permanent magnet flux switching motor technology as a solution for high torque clean electric vehicle drive," International Journal of Power Electronics and Drive System (IJPEDS), vol. 10, no. 2, pp. 575-584, 2019.

[8] F. A. Hasan and L. J. Rashad, "Fractional-order PID controller for permanent magnet DC motor based on PSO algorithm," International Journal of Power Electronics and Drive System (IJPEDS), vol. 10 no. 4, pp. 1724-1733, 2019.

[9] D. Mingardi and N. Bianchi, "Line-start pm-assisted synchronous motor design, optimization, and tests," IEEE Transactions on Industrial Electronics, vol. 64, no. 12, pp. 9739-9747, 2017.

[10] R. Vartanian and A.H.A.Toliat, "Design and comparison of an optimized permanent magnet-assisted synchronous reluctance motor (PMa-SynRM) with an induction motor with identical NEMA Frame stators," in Electric Ship Technologies Symposium (ESTS), Baltimore, USA, 2009, pp. 107-112, 2009.

[11] Q. Lin, et al., "Design and optimization of a reluctance-torque-assisted synchronous motor with high efficiency and low torque ripple," in 2019 22nd International Conference on Electrical Machines and Systems (ICEMS), Harbin, China, pp. 1-4, 2019.

[12] Won-ho Kim, et al., "Optimal PM design of PMa-SynRM for wide constant-power operation and torque ripple reduction", IEEE Transactions on Magnetics, vol. 45, no. 10, pp. 4660-4663, 2009.

[13] P.R. Viego, et al., "Direct-on-line-start permanent-magnet-assisted synchronous reluctance motors with ferrite magnets for driving constant loads," International Journal of Electrical and Computer Engineering (IJECE), vol. 10, no. 1, pp. 651-659, 2020.

[14] S. Huang, et al., "Optimization the electromagnetic torque ripple of permanent magnet synchronous motor." in 2010 International Conference on Electrical and Control Engineering, Wuhan, China, pp. 3969-3972, 2010.

[15] J. Li, H., et al., "Vibration analysis of permanent-magnet-assisted synchronous reluctance machines," in 2019 22nd International Conference on Electrical Machines and Systems (ICEMS), Harbin, China pp. 1-6, 2019.

[16] M. T. Bin Tarek, J. Herbert and S. Choi, "Analysis of unbalanced magnetic pull of permanent magnet assisted synchronous reluctance motor based on uneven axial temperature distribution of magnets," in 2017 IEEE International Electric Machines and Drives Conference (IEMDC), Miami, FL, pp. 1-6, 2017.

[17] B. Silwal, M. N. Ibrahim and P. Sergean, "Performance of PM-assisted synchronous reluctance machine under rotor eccentricity," in 2018 International Symposium on Power Electronics, Electrical Drives, Automation and Motion (SPEEDAM), Amalfi, pp. 319-323, 2018.

[18] B. Gaussens, et al., "Torque ripple mitigation of PM-assisted synchronous reluctance machine: design and optimization," in 2017 20th International Conference on Electrical Machines and Systems (ICEMS), Sidney, NSW, pp. 1-6, 2017.

[19] P. Niazi and H.A. Toliyat, "Design of a low-cost concentric winding permanent magnet assisted synchronous reluctance motor drive," in Fourtieth IAS Annual Meeting. Conference Record of the 2005 Industry Applications Conference, Kowloon, Hong Kong, vol. 3, pp. 1744-1748, 2005. 
[20] Wu Ren, et al., "Reducing cogging torque and suppressing torque ripple in PMASynRM for EV/HEV applications," in 2014 IEEE Conference and Expo Transportation Electrification Asia-Pacific (ITEC Asia-Pacific), Beijing, pp. 1-6, 2014.

[21] A. Tap, et al., "Effects of the rotor design parameters on the torque production of a PMaSynRM for washing machine applications", in 2017 International Conference on Optimization of Electrical and Electronic Equipment $($ OPTIM) \& 2017 Intl Aegean Conference on Electrical Machines and Power Electronics (ACEMP), Brasov, pp. 370-375, 2017.

[22] A. O. Dulanto, "Design of a synchronous reluctance motor assisted with permanent magnets for pump applications," M.S. Thesis, Dept. of Elec. Eng., KTH Royal Ins. of Technology, Sweden, 2016.

[23] H.C. Liu, et al., "Design of permanent magnet-assisted synchronous reluctance motor for maximized back-emf and torque ripple reduction," IEEE Transactions on Magnetics, vol. 53, no. 6, pp. 1-4, 2017.

[24] B. Kerdsup, et al., "Design of permanent magnet-assisted synchronous reluctance motors with maximum efficiency-power factor and torque per cost" in 2018 XIII International Conference on Electrical Machines (ICEM), Alexandroupoli, pp. 2465-2471, 2018.

[25] A. Tap, et al., "Effects of the stator design parameters on the torque performance of a PMaSynRM," in 2017 11th IEEE International Conference on Compatibility, Power Electronics and Power Engineering (CPE-POWERENG), Cadiz, pp. 346-351, 2017.

[26] C.M. Spargo, et al, "Application of fractional slot concentrated windings to syncronous reluctance motor", IEEE Transactions on Industry Applications, vol. 51, pp. 1446-1455, 2015.

[27] O. Payza, et al., "Investigation of losses for a concentrated winding high-speed permanent magnet-assisted synchronous reluctance motor for washing machine application," IEEE Transactions on Magnetics, vol. 54, no. 11, pp. 1-5, 2018.

[28] M. Gamba, et al., "A new PM-assisted synchronous reluctance machine with a nonconventional fractional slot per pole combination," in Optimization of Electrical and Electronic Equipment (OPTIM), 2014 International Conference, Bran, Romania, pp. 268-275, 2014.

[29] X. Cheng, et al., "Permanent magnet assisted synchronous reluctance machine with fractional-slot winding configurations," in 2013 International Electric Machines and Drives Conference, Chicago, IL, pp. 374-381, 2013.

[30] Kurnia, et al., "A low torque ripple PMSM drive for EPS applications", in Proceedings of the Nineteenth Annual IEEE Applied Power Electronics Conference \& Exposition (APEC), Anaheim, USA vol. 2, pp. 1130-1136, 2004.

[31] M. J. S. Zuberi, et al., "Techno-economic analysis of energy efficiency improvement in electric motor driven systems in Swiss industry", Applied Energy, vol. 205, pp. 85-104, 2017.

[32] Y. Özkara and M. Atak, "Regional total-factor energy efficiency and electricity saving potential of manufacturing industry in Turkey”, Energy, vol. 93, pp. 495-510, 2015.

[33] C.J. Verucchi, et al, "High efficiency electric motors: economic and energy advantages", IEEE Latin America Transactions, vol. 11, no. 6, pp. 1325-1331, 2013.

[34] Resolution No. 28-2011: "Electric rates for the non-residential sector", Ministry of Finance and Prices, Havana, 2011.

[35] E. Sierra, et al., "obtaining load Curves of Distribution transformers by Customers' Billings: Case Study," INGE CUC, vol. 10, no. 2, pp. 27-35, 2014.

[36] F. J. T. E. Ferreira, et al., "Overview of retrofitting options in induction motors to improve their efficiency and reliability," in 2018 IEEE International Conference on Environment and Electrical Engineering and 2018 IEEE Industrial and Commercial Power Systems Europe (EEEIC/I\&CPS Europe), Palermo, pp. 112,2018

[37] A.T. De Almeida, et al, "Technical and economic considerations on super high-efficiency three-phase motors", IEEE Transactions on Industry Applications, vol. 50, no. 2, pp. 1274-1285, 2014.

[38] J. Fong, et al., "IEC61800-9 system standards as a tool to boost the efficiency of electric motor driven systems worldwide", Inventions 2020, vol. 5, no. 20, pp 1-15, 2020.

\section{BIOGRAPHIES OF AUTHORS}

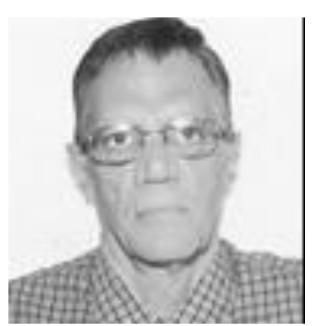

Percy R. Viego Felipe was born in Cienfuegos, Cuba, on November 19, 1944. Received a B.S degree in Electrical Engineering from the Universidad Central de Las Villas, Santa Clara, Cuba, in 1965. Received the Dr.C. (Ph.D.) degree from the Universidad Central de Las Villas, Santa Clara, Cuba. He has published articles on induction motors, energy quality, and energy efficiency in high impact journals indexed in Scopus and Wos. His current research interests include the analysis of electrical machines and drives, power quality and management, and energy efficiency. 


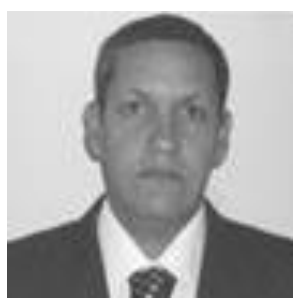

Julio R. Gómez Sarduy was born in Cienfuegos, Cuba, in 1956. Received a B.S degree in electrical engineering from Universidad Central de Las Villas, Santa Clara, Cuba, in 1986. Received an M.Sc. degree in electrical engineering from Universidad Central de Las Villas, Santa Clara, Cuba, in 1996, from where he received his Ph.D. degree in 2006. He has published articles on induction motors, energy quality, and energy efficiency in high impact journals indexed in Scopus and Wos. His area of interest includes electric machines, power quality, and energy efficiency in industrial power systems.

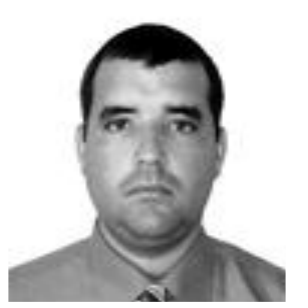

Vladimir Sousa Santos was born in Cienfuegos, Cuba, on November 21, 1980. Received a B.Sc. in Electrical Engineering from the Universidad Central de Las Villas, Cuba in 2004. M.Sc. in Energy Efficiency from Universidad Cienfuegos, Cuba in 2004. PhD. in Electrical Engineering from Universidad Central de Las Villas, Cuba, in 2014. He has published articles on induction motors, energy quality, and energy efficiency in high impact journals indexed in Scopus and Wos. His area of interest includes electric machines, power quality, and energy efficiency.

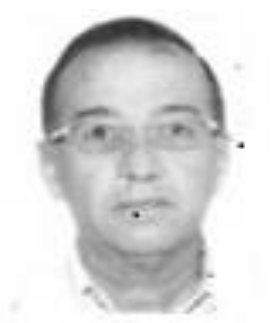

José P. Monteagudo Yanes was born in Santa Clara, Cuba, in 1947. Received the B.S. degree in Mechanical Engineering from Universidad Central de Las Villas (UCLV), Santa Clara, Cuba, in 1975. Received the Dr.C. (Ph.D.) degree from the Instituto Superior Politécnico "José A. Echeverría, La Habana, Cuba in 1997. Full Professor and Consultant Professor. Currently is with the Center of Energy and Environmental Studies (CEEMA), Faculty of Engineering, Universidad de Cienfuegos, Cuba. His areas of interest are flow machines, energy management and renewable energy sources.

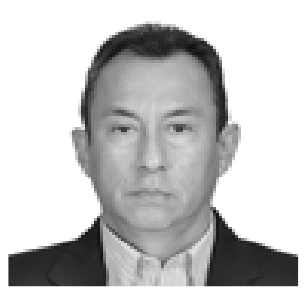

Enrique C. Quispe Oqueña was born in Lima, Perú, on January 20, 1956. Received a B.Sc. in Electrical Engineering from the Universidad Nacional de Ingeniería, Perú in 1980. M.Sc. in Electrical Engineering, M. Eng. in Industrial Automation and PhD. in Electrical Engineering from Universidad del Valle, Colombia in 1994, 1997, and 2012, respectively. He has published articles on induction motors, energy quality, and energy efficiency in high impact journals indexed in Scopus and Wos. His current research interests include the analysis of electrical machines and drives, power quality and management, and energy efficiency.

Dr. Quispe is an IEEE Senior Member. 